\title{
RATIONALE FOR REFERRING CLASS II PATIENTS FOR EARLY ORTHODONTIC TREATMENT
}

\author{
AS RAZÕES PARA INDICAÇÃO DE TRATAMENTO PRECOCE \\ EM PACIENTES DE CLASSE II
}

José Augusto Mendes MIGUEL ${ }^{1}$, Deise Lima CUNHA², Anderson de Albuquerque CALHEIROS², Daniel KOO²

1- DDS, MSc, PhD, Adjunct Professor, Department of Orthodontics at State University of Rio de Janeiro (UERJ), Rio de Janeiro, Brazil.

2- DDS, MSc, Graduate Student in Orthodontics, State University of Rio de Janeiro (UERJ), Rio de Janeiro, Brazil.

Correponding address: José Augusto Mendes Miguel - Rua Mem de Sá, 19 sala 706 . Icaraí - Niterói - RJ - Cep.: 24220261

Tel/fax: (0XX21) 2717-4490 - e-mail: j.a.miguel@terra.com.br

Received: December 10, 2004 - Modification: February 28, 2005 - Accepted: May 09, 2005

\begin{abstract}
7

he tendency of indicating early treatment (before growth spurt) when dealing with Angle Class II cases has been noticed, although there is no definite scientific evidence to justify such decision. The aim of this study was to identify the advantages and disadvantages to this approach and which appliances are used for this purpose. For that purpose, a questionnaire containing full records of a Class II patient was sent to two professors of each Orthodontic graduate program in Brazil (n=96, total 192), from which 107 were properly answered. Results demonstrated that the most used appliances were the headgear (80.4\%), maxillary splint (50\%) and Bionator (44.4\%). The benefits most often quoted were increase of patient self-esteem (78.5\%) and reduction in the incidence of incisors trauma (63.6\%), while the main disadvantage was saturation of patient compliance (73.8\%). Considering early Class II treatment, there is still no unanimity as to treating in one or two stages or in selection of appliances. However, the orthodontists should consider the physical situation of the patient, severity of cases and susceptibility of trauma to the maxillary incisors. It is crucial that updated information is given to parents, in order to justify this approach.

Uniterms: Angle class II malocclusion; Orthodontics; Growth; Early treatment.
\end{abstract}

\section{RESUMO}

A

tendência de indicação de tratamento precoce (antes de surto de crescimento) para casos de Classe II de Angle tem sido observada, embora não haja evidência científica para embasar tal decisão. O objetivo deste estudo foi identificar as vantagens e desvantagens da indicação e quais aparelhos são usados no tratamento. Foram enviados questionários (n=192) com a documentação completa de um paciente Classe II para dois professores de cada curso de especialização em Ortodontia no Brasil, os quais 107 foram respondidos. Os resultados demonstraram que os aparelhos mais usados foram: Extra-oral (80,4\%), Thurow (50,0\%) e Bionator (44,4\%). Foram citados como maiores vantagens: aumento de auto-estima do paciente (78,5\%) e a redução da incidência de trauma nos dentes incisivos (63,6\%), por outro lado a principal desvantagem citada foi a saturação de cooperação do paciente (73,8\%). Considerando o tratamento precoce de Classe II não houve o consenso se a correção deveria ser realizada em duas ou em uma única fase e nem a seleção do aparelho a ser utilizado. Porém os ortodontistas deveriam levar em consideração o estado psicológico do paciente, a severidade do caso clínico e a susceptibilidade a trauma dos incisivos superiores. É importante que os responsáveis sejam esclarecidos quanto à necessidade do tratamento precoce.

Unitermos: Maloclusão de Angle classe II; Ortodontia; Crescimento; Tratamento precoce. 


\section{INTRODUCTION}

Class II malocclusion is a skeletal discrepancy that may be caused by maxillary protrusion, mandibular retraction or a combination of both situations. The treatment can be carried out at three different moments: the first during the pre-puberty stage (early treatment), when headgear or functional appliances would be used to develop an early change in the growth pattern; the second would be during maximum pubertal growth spurt, when the orthodontist would interfere with the problem in order to produce dentoalveolar movements and skeletal changes; and finally during adulthood, when due to growth absence the extraction of maxillary premolars is practically always considered, or even orthognathic surgery in more severe cases.

Even if it is not based on scientific evidence, which justifies the superiority of the two-stage treatment, and in spite of the controversial arguments discussed by many researchers in the literature, as well as in the professional environment, a strong tendency indicating the Class II early treatment can be observed nowadays ${ }^{7,8,10}$. Besides the real benefit that an early treatment may provide, another point that involves such issue and also generates many different opinions is the type of appliance that would be more indicated in the first stage, as a description of many of them can be found in the literature.

It has been observed that authors are committed to carry out a more critical analysis of the concepts regarding the effectiveness and efficiency of the two-stage treatment, as well as researches that show the real effects of the different types of appliances used in the first stage treatment. These conclusions are mainly derived from the results of prospective works, with adequate methodology to evaluate the real advantages of the two treatment options.

An efficient way to evaluate the professional approach today is to know the philosophy adopted in the graduate program, which may influence orthodontists in their daily practice or those undertaking specialization courses. The aim of this paper was to identify the benefits and advantages of the early orthodontic treatment of Class II malocclusion, as well as which appliances are mostly used in the first stage, according to the opinion of orthodontics professors from all over the country.

\section{METHODS}

TABLE 1- Frequency of use of a determined appliance in the Class II malocclusion early treatment between groups that indicated and did not indicate the early treatment for the proposed clinical case $(n=107)$

\begin{tabular}{|c|c|c|c|c|c|c|}
\hline \multirow[t]{2}{*}{$\begin{array}{l}\text { Uses some type } \\
\text { of appliance }\end{array}$} & \multicolumn{2}{|c|}{$\begin{array}{l}\text { Indicated the early } \\
\text { treatment }\end{array}$} & \multicolumn{2}{|c|}{$\begin{array}{l}\text { Did not indicate the } \\
\text { early treatment }\end{array}$} & \multicolumn{2}{|c|}{ Total } \\
\hline & $\mathrm{n}$ & $\%$ & $\mathrm{n}$ & $\%$ & $\mathrm{n}$ & $\%$ \\
\hline Yes & 82 & $100 \%$ & 23 & $92.0 \%$ & 105 & $98.1 \%$ \\
\hline No & 0 & $0.0 \%$ & 2 & $8.0 \%$ & 2 & $1.9 \%$ \\
\hline Total & 82 & $76.6 \%$ & 25 & $23.4 \%$ & 107 & $100 \%$ \\
\hline
\end{tabular}

Standardized data collection was used. This was performed by means of a questionnaire (to which a clinical case was enclosed), which was sent to all institutions offering an Orthodontic graduate program in the country $(n=96)$. Two questionnaires were sent to each course (total 192), so that different opinions within the same institution could be identified. The questionnaire was composed of two parts: the first section presented the case report a 10year-old female with moderately severe Class II division 1 malocclusion, skeletal age 2 years before the pubertal growth spurt, including photographs of the face (frontal, profile and smiling) and intraoral photographs (frontal, lateral and occlusal), panoramic radiographs and cephalometric analysis. In the second section of the questionnaire, questions related to options available in literature were included, in order to find out, among other issues, the professionals' opinion, that is, whether early treatment should be applied to that case or not, the type of appliance that should be used if the first stage of treatment were to be indicated, as well as the advantages and disadvantages of this type of treatment. Data were processed and analyzed using the Epi-Info 6.04 software. The answers to the questions were descriptive (percentage); however, opinions of the groups that had different working philosophies were compared by means of the chi-square analysis.

Of the 192 questionnaires, 107 (55.72\%) were sent back, being classified as valid and ready to be analyzed. Considering the 96 Brazilian Institutions that offer an Orthodontic program, which were contacted, 58 (60.41\%) collaborated with the answers.

The aim of the questionnaire was to evaluate which appliances are usually chosen by professors in the early treatment of Class II malocclusion, considering that professors could select more than one alternative. In Table 1 , it can be observed that $76.6 \%$ of the interviewed professors said that they would adopt the early treatment for the case considered in the questionnaire, i.e. they would indicate some type of appliance for the first stage. Analysis of data distribution in Figure 1 shows that $80.4 \%$ of the orthodontists reported that they would choose the headgear, followed by maxillary splint (50.0\%) and Bionator (44.4\%). An important fact was that 23 professionals (90\%) that had

\section{RESULTS}


not indicated early treatment for the proposed clinical case recommend some type of appliance (Table 1 and Figure 1 ).

The advantages mostly mentioned for the early treatment modality were: it helps to improve patient self-esteem and brings satisfaction to the family (78\% of the questionnaires); this opinion was common to both groups. Other advantages mentioned were reduction of risk of anterior teeth fracture (63.6\%), shorter orthodontic treatment during the second stage (62.6\%), as well as reduction of extraction (61.7\%). However, as it can be seen in Table 2, there was a significant difference $(p<0.01)$ regarding the frequency of such opinions among professors indicating or not treatment for the case proposed in the questionnaire.

Concerning the disadvantages of the Class II early treatment, it was noticed that even among the professionals who indicated early intervention for the proposed case, 56 (68.3\%) mentioned saturation of patient compliance and 50 $(61.0 \%)$ referred to time increase and treatment cost as negative aspects of such approach (Table 3). The difference between groups was significant $(\mathrm{p}<0.05)$ for the following disadvantages: 1) Few orthopedic benefits can be obtained at this treatment stage, 2) Equal results could be obtained with less treatment time. In general, saturation of patient compliance was considered the greatest disadvantage of this type of treatment (79 professionals, $73.8 \%$ of the total sample).

\section{DISCUSSION}

The pre-puberty intervention, called early treatment, generates discussions in the orthodontic environment due to the fact that "early" leads to "premature, anticipated" and consequently seems to be done before the ideal time. Because of this, many authors prefer to name it as a twostage treatment, with the first stage taking place before the growth spurt and a second at the end of mixed dentition. One of the objectives of this study was to determine which would be the mostly used appliance in the first stage to correct skeletal discrepancies. According to the data

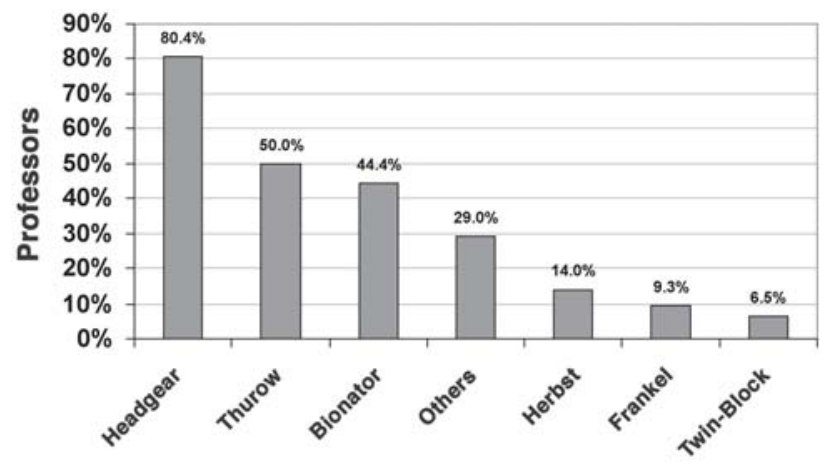

Appliances

FIGURE 1- Frequency of use of different types of orthodontic appliances adopted by professors for the Class II malocclusion early treatment $(n=107)$

TABLE 2- Benefits mentioned by professors for the Class II malocclusion early treatment

\begin{tabular}{|c|c|c|c|c|c|c|c|}
\hline \multirow{2}{*}{$\begin{array}{l}\text { Benefits that a patient with } \\
\text { Class II malocclusion may } \\
\text { obtain when the early } \\
\text { treatment is applied. }\end{array}$} & \multicolumn{2}{|c|}{$\begin{array}{l}\text { Indicated the early } \\
\text { treatment } \\
n=82(76.6 \%)\end{array}$} & \multicolumn{2}{|c|}{$\begin{array}{l}\text { Did not indicate the } \\
\text { early treatment } \\
n=25(23.4 \%)\end{array}$} & \multirow[t]{2}{*}{ p value } & \multicolumn{2}{|c|}{$\begin{array}{l}\text { Total sample } \\
n=107(100 \%)\end{array}$} \\
\hline & $\mathrm{n}$ & $\%$ & $\mathrm{n}$ & $\%$ & & $\mathrm{n}$ & $\%$ \\
\hline $\begin{array}{l}\text { Patient self-esteem } \\
\text { improvement and family } \\
\text { satisfaction }\end{array}$ & 65 & $79.3 \%$ & 19 & $76 \%$ & $p=0.72$ & 84 & $78.5 \%$ \\
\hline $\begin{array}{l}\text { Capability to modify the growth } \\
\text { process }\end{array}$ & 51 & $62.2 \%$ & 6 & $24.0 \%$ & $p=0.0008^{*}$ & 57 & $53.3 \%$ \\
\hline Greater patient compliance & 34 & $415 \%$ & 3 & $12 \%$ & $p=0.006^{*}$ & 37 & $34.6 \%$ \\
\hline $\begin{array}{l}\text { More stable results may be } \\
\text { acquired }\end{array}$ & 50 & $61.0 \%$ & 4 & $16 \%$ & $p=0.00008^{*}$ & 54 & $50.5 \%$ \\
\hline $\begin{array}{l}\text { Less extensive orthodontic } \\
\text { treatment during the } 2 \text { nd stage }\end{array}$ & 59 & $72.0 \%$ & 8 & $32 \%$ & $p=0.0003^{*}$ & 67 & $62.6 \%$ \\
\hline $\begin{array}{l}\text { Reduction of risk of anterior } \\
\text { teeth fracture }\end{array}$ & 52 & $63.4 \%$ & 16 & $64.0 \%$ & $p=0.95$ & 68 & $63.6 \%$ \\
\hline More treatment possibilities & 25 & $30.5 \%$ & 1 & $4.0 \%$ & $p=0.006^{*}$ & 26 & $24.3 \%$ \\
\hline Better use of growth potential & 56 & $68.3 \%$ & 1 & $4.0 \%$ & $p=0.00000^{*}$ & 60 & $56.1 \%$ \\
\hline Reduction of need of extraction & 58 & $70.7 \%$ & 8 & $32.0 \%$ & $p=0.0004^{*}$ & 66 & $61.7 \%$ \\
\hline Better final results & 50 & $61.0 \%$ & 3 & $12.0 \%$ & $p=0.00001^{*}$ & 53 & $49.5 \%$ \\
\hline Lower treatment cost & 11 & $13.4 \%$ & 1 & $4.0 \%$ & $p=0.19$ & 12 & $11.2 \%$ \\
\hline
\end{tabular}


collected, the appliance mostly used by the inquired professionals was the headgear (80.2\%).

Different works that compared the effects of functional appliances with the headgear when treating children with Class II malocclusion reached the conclusion that both appliances presented successful results (ANB reduction). The use of headgear significantly reduced the SNA, while the functional appliance altered the anterior mandible position, increasing the SNB ${ }^{6,11}$. It should be said that, most of the times, this statistical difference does not represent clinical discrepancies between appliances.

This information reinforces the idea that preference for a special appliance seems to be related to the influence of approaches observed by professionals during their training in graduate courses, rather than a theoretical base by experiences acquired in prospective studies. Some authors claim that functional appliances must be used for cases of Class II malocclusion with specific characteristics, such as horizontal growth pattern, small sagittal discrepancy between the maxilla and mandible, retroclined mandibular incisors and a retruded upper $\operatorname{lip}^{1,15,13}$.

The lack of a common sense on the real benefit of the Class II early treatment is reflected in the great number of advantages and disadvantages described in the literature for such procedure. The data collected showed that the mostly considered benefit for the early treatment choice is that it improves patient self-esteem and brings satisfaction to the family (78.5\%). Many professionals take into consideration the patient's psychological aspects, as in many cases they become quite insecure, because the esthetic problem makes them feel inferior in relation to their friends ${ }^{9}$. According to Tung and Kiyak ${ }^{16}$, at the age of 8 a child already has a definite esthetic pattern as an adult. When a child believes that he or she is attractive, this will allow him or her to be well accepted by the society and relatives. This child will also believe to be more intelligent than others and has greater talent to be in a prominent place in society. For many authors, the decision to carry out the two-stage treatment is directly related to the patient's psychological situation, as well as when malocclusion becomes uncomfortable for the patient.

Although the researches carried out by Dann et $\mathrm{al}^{5}$ did not indicate a significant difference regarding the self-esteem of patients submitted to early treatment, in some isolated cases it can be observed that this approach could be beneficial. Particularly in patients with severe malocclusion, waiting for correction may generate extreme anxiety, causing harm to the psychosocial development of the growing individual ${ }^{17}$.

In a study carried out by Tulloch ${ }^{15}$, it was verified that patients submitted to the Class II early treatment presented less incidence of injury to the maxillary incisors when compared to the control group. This is in agreement with the opinion of professors that participated in the research and pointed out the reduction of risk of fracture of anterior teeth as the second greatest advantage of the two-stage treatment (63.6\%).

The third greatest advantage of this type of approach was the shorter orthodontic therapy during the second stage (62.6\%). This benefit was verified by a research where orthodontists' perception regarding the impact of the firststage treatment was analyzed. These professionals concluded that the only significant benefit was reduction in the treatment difficulty, as well as the need to use full-mouth appliance at the second stage ${ }^{12}$.

It was verified that 7 of the 11 listed benefits were mentioned by more than $50.0 \%$ of the professors. The items less mentioned by professionals were lower treatment cost (11.2\%), more treatment possibilities (24.3\%), and more patient compliance (34.6\%). When the sample was separated between professionals that had indicated treatment or not for the clinical case considered in the questionnaire, it was possible to notice a significant difference in the rate of professionals that pointed each of the items that offered advantages for the early treatment (Table 1 ). This difference means that the group that indicated an early approach for

TABLE 3- Disadvantages mentioned by professors for the Class II malocclusion early treatment

\begin{tabular}{|c|c|c|c|c|c|c|c|}
\hline \multirow{2}{*}{$\begin{array}{l}\text { Disadvantages when the early } \\
\text { treatment is applied. } \\
\text { Patient unable to cooperate due } \\
\text { to lack of maturity }\end{array}$} & \multicolumn{2}{|c|}{$\begin{array}{l}\text { Indicated the } \\
\text { early treatment } \\
\mathrm{n:} \mathbf{8 2 ( 7 6 . 6 \% )}\end{array}$} & \multicolumn{2}{|c|}{$\begin{array}{l}\text { Did not indicate } \\
\text { the early treatment } \\
n: 25(23.4 \%)\end{array}$} & \multirow{2}{*}{$\begin{array}{l}\text { p value } \\
p=0.102\end{array}$} & \multicolumn{2}{|c|}{$\begin{array}{l}\text { Total sample } \\
\mathrm{n}: 107(100 \%)\end{array}$} \\
\hline & 27 & $32.6 \%$ & 4 & $16.0 \%$ & & 31 & $29.0 \%$ \\
\hline $\begin{array}{l}\text { Few orthopedic benefits, as } \\
\text { patient is not in the pubertal growth } \\
\text { spurt }\end{array}$ & 9 & $11.0 \%$ & 16 & $64.0 \%$ & $p=0.000^{*}$ & 25 & $23.4 \%$ \\
\hline Saturation of patient compliance & 56 & $68.3 \%$ & 23 & $92.0 \%$ & $p=0.018^{*}$ & 79 & $73.8 \%$ \\
\hline Time increase and treatment cost & 50 & $61.0 \%$ & 4 & $16.0 \%$ & $p=0.070$ & 70 & $65.4 \%$ \\
\hline Less stability in the results & 4 & $4.9 \%$ & 0 & $0.0 \%$ & $p=0.200$ & 4 & $3.7 \%$ \\
\hline $\begin{array}{l}\text { Same result can be obtained with } \\
\text { less treatment time. }\end{array}$ & 13 & $15.9 \%$ & 12 & $48.0 \%$ & $p=0.000^{*}$ & 25 & $23.4 \%$ \\
\hline
\end{tabular}

* significant $(p<0.01)$ 
the case recognizes the benefits as a real justification for the treatment. Although by clinical approaches some of these advantages can in fact be identified, this must be scientifically verified in order to prove that this will occur in a consistent way and not in isolated cases.

When Table 3 is analyzed, it can be noticed that $73.8 \%$ of the professionals considered compliance saturation as a disadvantage when dealing with the early treatment approach. When literature related to patient compliance is evaluated, many authors believe that younger patients are more compliant regarding the use of appliances than adolescents ${ }^{4,14}$. However, it is important to emphasize that if the treatment takes too long or depends too much on the child, a reduction in child compliance and collaboration may occur.

Many authors agree that the early treatment (first stage) will simplify and reduce the second stage, besides providing more opportunities for the use of growth modification therapies ${ }^{2,3,12}$. The participants of this work are in agreement with the information regarding the shorter orthodontic therapy during the second stage $(62.6 \%)$, but only $24.3 \%$ believe that the two-stage treatment would allow more treatment possibilities.

The attitudes of professors reported in this work show that there is a concern regarding early diagnosis and treatment for the Class II malocclusion. However, there is still no unanimity in the literature in stating that treatment at an early age is able to alter the growth pattern of the patient. In fact, some studies suggest that the patient should be treated during the growth stage, but the moment makes no difference in the final treatment success ${ }^{18}$. In patients with serious skeletal problems, a longer time is needed to obtain the desired growth changes. In these cases, the early treatment approach allows a reduction in the period of utilization of fixed appliances, which many times are kept for a longer period in order to obtain the desired skeletal balance. As a consequence, the one-stage approach in most cases would offer more advantages when compared to the twostage procedure, mainly when considering time reduction and treatment cost. However, other factors should be taken into consideration, such as the patient's psychological situation, severity of the case and trauma susceptibility to the maxillary incisors; these factors would justify treatment at an early age ${ }^{15}$. Therefore, the decision for the best moment to carry out intervention should be taken according to the patient and family characteristics, as social uneasiness can be by itself a determining factor for such intervention. Thus, analysis of the most recent studies reveals that the onestage treatment, as well as the two-stage treatment, allows Class II malocclusion cases to be treated more effectively. Therefore, the patient should be informed that early therapy is not the only way to obtain a good result, and the advantages and disadvantages of these two modalities should be analyzed in order to decide which would be the best treatment plan, according to the psychological, social and economic characteristics of each patient ${ }^{19}$.

It is important to point out that the results of this study show only the opinions of professionals on early Class II treatment, regardless if these concepts are in accordance with recent evidence-based information.

It is crucial to go looking on for concrete guidelines to help on the decision of Class II correction strategy, in order to have a guarantee that the best and more efficient treatment is being offered to our patients. These concepts must be based on scientific evidence and results of randomized studies, so that Class II first-stage treatment would only be considered when, in fact, it could be demonstrated in which specific cases it offers advantages when compared to the one-stage traditional therapy.

\section{CONCLUSIONS}

1. According to the interviewed Brazilian professors, the main advantages of Class II early treatment were: raise patient self-esteem and family satisfaction (78.5\%), reduction of risk of anterior teeth fracture (63.6\%), and less extensive orthodontic therapy during the second stage (62.6\%). The main disadvantages were saturation of patient compliance (73.8\%) and increased treatment cost (65.4\%). However, these advantages were not reported in scientific data.

2. According to the questionnaires, the method mostly used for early treatment was the headgear (80.4\%), followed by maxillary splint (50.0\%) and by Bionator (44.4\%).

\section{ACKNOWLEDGEMENTS}

The authors would like to thank the helpful contribution of Dr. Vera Soviero for the elaboration of this work, as well as all the professors that kindly answered to the questionnaire.

\section{REFERENCES}

1- Ahn S, Kim J, Nahm, D. Cephalometric markers to consider in the treatment of Class II division 1 malocclusion with the Bionator. Am J Orthod Dentofac Orthop. 2001;119:578-86.

2- Barrer GH. Treatment timing onset or onslaught? J Clin Orthodont. 1971;5:191-9.

3- Bishara SE, Justus R, Graber TM. Proceedings of the workshop discussions on early treatment. Am J Orthod Dentofac Orthop. 1998;113:132-6.

4- Cucalon A, Smith RJ. Relationship between compliance by adolescent orthodontic patients and performance on psychological tests. Angle Orthod. 1990;60:107-14.

5- Dann C, Phillips C, Broder HL, Tulloch JF. Self-concept, Class II malocclusion and early treatment. Angle Orthod. 1995;65:411-6.

6- Ghafari J, Shofer FS, Jacobsson-Hunt U et al. Headgear versus function regulator in the early treatment of class II, division 1 malocclusion: A randomized clinical trial. Am J Orthod Dentofac Orthop. 1998;113:51-61.

7- Gianelly AA. Crowding: Timing of treatment. Angle Orthod. 1994;6:415-8. 
8- Gianelly AA. A strategy for nonextraction class II treatment. Semin in Orthod. 1998;4:26-32.

9- Jakobsson SO. Psychology and early orthodontic treatment. Am J Orthod. 1979; 32: 511-29.

10- Jetson SL, Dugoni SA. Mixed dentition treatment case report. Am J Orthod Dentofac Orthop. 1987;4:335-41.

11- Keeling SD, Wheeler TT, King GJ et al. Anteroposterior skeletal and dental changes after early class II treatment with Bionators and headgear. Am J Orthod Dentofac Orthop. 1998;113:123-32.

12- King GJ, Wheeler TT, McGorray SP et al. Orthodontists' perceptions of the impact of phase 1 treatment for class II malocclusion on phase 2 needs. J Dent Res. 1999;78:1745-53.

13- Livieratos FA, Johnston LE. A comparison of one-stage and twostage nonextraction alternatives in matched Class II samples. Am J Orthod Dentofac Orthop. 1995;108:118-31.

14- Nanda RS, Kierl MJ. Prediction of cooperation in orthodontic treatment. Am J Orthod Dentofac Orthop. 1992;102:15-21.

15- Tulloch JFC et al. Benefit of early class II treatment: Progress report of a two-phase randomized clinical trial. Am J Orthod Dentofac Orthop. 1998;113:62-71.

16- Tung AW, Kiyak HA. Psychological influences on the timing of orthodontic treatment. Am J Orthod Dentofac Orthop. 1998;113:2939.

17- O’Brien K, Wright J, Conboy F, Chadwick S, Connolly I, Cook P. Effectiveness of early orthodontic treatment with the twin-block appliance: a multicenter randomized, controlled trial. Part 2: psychosocial effects. Am J Orthod Dentofac Orthop. 2003;124:48895

18- Tulloch JFC, Phillips C, Proffit WR. Outcomes in a 2-phases randomized clinical trial of early class II treatment. Am J Orthod Dentofac Orthop. 2004;125:657-67.

19- Proffit RW. The timing of orthodontic treatment: effectiveness and efficiency. Rev Odont Stomot. 2003;32:171-89. 